\title{
The Study of Symbolic Interaction of Funeral Tradition on Ethnic Chinese in Lombok
}

\author{
${ }^{1}$ Anthony Anggrawan, ${ }^{2}$ Mayadi \\ ${ }^{1}$ Computer Science, Universitas Bumigora, Indonesia, e-mail : \\ anthony.anggrawan@universitasbumigora.ac.id \\ 2Information Technology, Universitas Bumigora, Indonesia, \\ e-mail : mayadi.yadot@universitasbumigora.ac.id
}

\section{Article history:}

Received : 22-08-2020

Reviced : 10-09-2020

Accepted : 28-09-2020

\section{Keyword:}

Funeral Ritual;

Symbol;

Ethnic Chinese;

Deceased;

Burial Culture;

Heritage.

\section{ABSTRAC}

There are various burial cultures in Indonesia, including the Chinese ethnic burial culture. What is interesting in almost all burial cultures is the cultural heritage that has been passed down through generations. The question is how actually the ceremonial Chinese ethnic funeral ritual is, and what the symbols in the ethnic Chinese funeral ritual mean. This research provides an answer solution. This research is a qualitative research. The results of the study concluded that before the funeral ritual is carried out, younger family members pay their respects to the older deceased. During the funeral ritual, the next of kin accompany the vehicle carrying the body to the burial or cremation site, on foot, if the burial place is relatively close, or by vehicle if the burial place is far away. During the funeral, flowers, offerings, food and burnt incense are served. The culture of the Chinese funeral ritual was based on belief as a form of human relations with the creator of life and also as a way to maintain the symbol of family or relatives with the deceased and to bear the sins of the deceased.

This is an open access article under the CC BY-SA license.

DOI: https://doi.org/10.30812/varian.v4i1.854

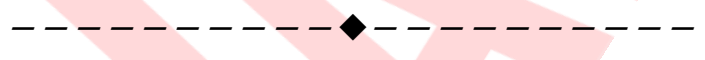

\section{A. INTRODUCTION}

Indonesia is a nation that is rich in local cultural diversity inherent in each tribe and ethnicity who live in various islands or provinces of Indonesia. The diversity of Indonesia's local culture is one of the very unique characteristics of the Indonesian nation. It is very unique because what generally happens is that a group of people forms a nation based on cultural similarities, but Indonesia is actually formed from cultural diversity and cultural differences. Among the thousands of cultures that exist in Indonesia, one of them is the Chinese burial culture which has socio-historical values.

In fact, the Chinese ethnic community is a unique and rare blend of original Chinese culture with local ethnic culture in countries outside China (Sankar et al., 2016). According to the previous research findings, the response to death by doing mourning processions and others reflects the cognitive, affective and attitude behaviour of the individual towards death (Yick \& Gupta, 2012). Since many believe that death is universal, it is not surprising that attitudes and processions of death vary widely in the world (Yick \& Gupta, 2012). The biggest difference in the death procession is the belief in death and the meaning of the death procession 
(Yick \& Gupta, 2012). That is why it is important to reveal the variations that exist in the death procession or the funeral ritual so as to reveal the meaning of the belief contained in all the signs in the ceremonial procession of death.

The semiotic theory deals with the use of signs. Signs included in the semiotic theory are anything g, both physical and mental, that has meaning or is given meaning human. So a sign will only be a sign if the sign has meaning for humans. Objects governed by the rules in their use, are only one of the three categories of signs defined which Peirce calls a symbol. Symbols are signs that refer to objects based on rules, usually a relation of common ideas, which causes the symbol interpreted based on the object (Thornbury, 2011). The customs of the ethnic Chinese funeral ritual are Chinese mythology of the Gods, involving many traditional activities that are part of the funeral ritual. So it implies that the customs in the Chinese ethnic procession contain signs that are meaningful to the Chinese community (Sankar et al., 2016). Keeping in mind that Chinese ethnic funeral ritual has a meaningful sign for the Chinese community. Thus, research to reveal the meaning of signs used in ethnic Chinese funeral rituals, such as signs wearing all-white clothes, burning incense, and others, is closely related to semiotic theory and it is important to research to reveal its true meaning.

\section{B. LITERATURE REVIEW}

\section{History of the Chinese Ethnic Society}

The ethnic Chinese-Indonesian ancestors immigrated thousands of years ago through commercial activities. Records from China state that the ancient kingdoms in the archipelago were closely related to the ruling dynasty in China. This factor then fertilizes the trade and traffic of goods and people from China to the archipelago and vice versa. Ethnic Chinese came to the island of Lombok in the 18th century via Labuhan Haji, East Lombok. At that time, Chinese ethnicity controlled the trade and industrial sectors in Labuhan Haji, this is evidenced by the many buildings and former factories that were left in the area. The Chinese community left Labuhan Haji in 1965 and most of those who chose to settle on the island of Lombok moved to several cities such as Ampenan, Mataram, Cakranegara, Praya and other cities outside the island of Lombok such as Surabaya, Sulawesi and East Nusa Tenggara. The Chinese community on the island of Lombok, especially those living in the city of Ampenan, still strongly maintains the original Chinese culture. Apart from the culture of the Chinese community, they also maintain the ability to speak Mandarin and / or local Chinese. The life activities of the Chinese community are closely related to the teachings of their ancestors, to have a safe life in the world and hope for happiness after death.

\section{Funeral Ritual of the Chinese Ethnic Society}

Chinese ethnic burial culture has a connection with ghost superstition as a legacy of the past that was born purely from ancestral worship. However, in recent times the superstition of ghosts has been marginalized and faded from the cultural vision of the Chinese ethnic (Bo \& Wei-wei, 2012). The tradition of traditional death ceremonies based on Chinese ethnic culture is carried out by the head of the household or the parents of the deceased. Death ceremonies and funerals are an element of the culture inherent in the Chinese ethnic community. After all, funeral rituals are not only related to culture but also emotion (Lin, 2013). That is why, the Chinese funeral ritual brings many interested parties to the procession, thus, not only brings a unique visual pleasure from the funeral ritual but also with the arrival of colleagues, and families contribute to tying kinship ties, as well as restructuring interpersonal relationships (He, 2016). The customs of the Chinese ethnic funeral ritual reflect that the social identity of the Chinese community is the child's obedience to serve their parents and the strictness in the implementation of customs (Sankar et al., 2016).

There are various important signs in every funeral ritual, including sadness, attitude or behavior, and mourning clothes that reflect the cultural function and social influence of symbols of different cultural and ethnic backgrounds ( $\mathrm{Wu}, 2015)$. So it is not surprising that in fact, the funeral ritual in ethnic Chinese contains ethnic symbols that have a special meaning. In a scientific study, it is said that the Chinese ethnic funeral ceremony is the way the Chinese community maintains the symbol of "Chinese" (Crowder, 2000). The wages given to diggers and casket carriers are wrapped in red envelopes as a sign of good luck, while 
the white clothes worn by the family are a sign of mourning (Toulson, 2013). For Chinese ethnicity, ancestors are considered as part of the family, which is equal to life in the world (Pasacreta, 2005). Families who have died have the same needs as human needs in the world such as food, housing, money, etc., it is the responsibility of families in the world to provide them (Pasacreta, 2005). The form of offering these needs to the deceased is done through food served and / or burning prayer paper, miniature houses, or clothes (Pasacreta, 2005).

\section{Peirce's Triadic Structure Theory (Peirce's Trichotomy)}

Semiotics or sign science presupposes a set of assumptions and concepts which make it possible to analyze symbolic systems in a systematic way. Although semiotics takes the initial model of verbal language, verbal language is only one of the many sign systems that exist on earth. Morse code, music, traffic signs fall within the reach of semiotics. A sign is something that describes something else in the mind that thinks.

The development of semiotics cannot be separated from the theory presented by Charles Sanders Peirce, who is considered the Father of Semiotics. Charles Sanders Peirce is famous for his theory called the theory of signs (Yakin \& Totu, 2014). His theory focuses more on signs. Signs have two aspects, namely as a marker and a sign. Semiotics deals with everything related to signs. A sign is anything that must actually exist or be present. Pierce classifies signs by visualizing triadic relationships that is, the relationships between three elements (Farias \& Queiroz, 2017). Peirce argues that the sign is formed through a triangular relationship or what is commonly called Peirce's triadic structure or Peirce's trichotomy. In other word, in Peirce's theory the sign is in a triangular relationship .

The object that is referred to by a sign, or something trichotomy whose presence is replaced by a sign, is a "reality" that is whatever is thought to exist. This means that the object does not have to be concrete or a reality, but can be abstract, imaginary, and fictional. Peirce's trichotomy principle can be used to differentiate the process into three relationships which are natural ways of expressing information (Widmeyer \& Arbor, 2003). The triangle image of Peirce's theory is shown in figure 1.

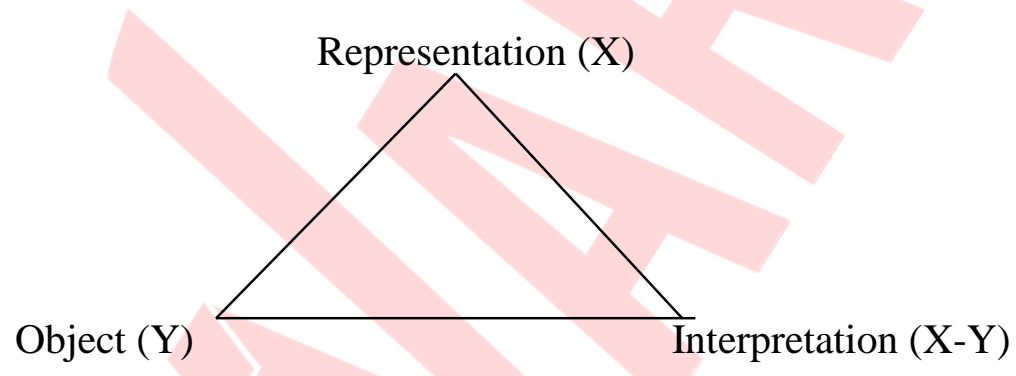

Figure 1. Image of Pierce's Theory

Representation is something that is sensory or material as a sign. A sign gives rise to an interpretation, which is another sign which is equivalent to it or in other words, is a set of interpretations. The object is everything that the sign refers to.

\section{RESEARCH METHOD}

This research is limited to the scope of research on the funeral ritual of the Chinese community in Ampenan, Lombok, West Nusa-Tenggara, Indonesia, including in exploring the meaning information contained in each sign in the funeral ritual. Data collection was carried out by conducting interviews with a senior member of the Chinese community and a person who was accustomed to being used in managing the death and funeral rituals of Chinese people in Lombok. The interview focused on open-ended questions to explore everything related to how the Chinese ethnic funeral ritual was, and what the symbolic meaning of the Chinese ethnic funeral ritual in Lombok was. 


\section{RESULT AND DISCUSSION}

\section{Ceremonial Chinese Ethnic Funeral Ritual}

Chinese ethnic funeral rituals are a customary tradition of the ancestors. In general, funeral rituals are carried out for 3 to 7 days, depending on the time of attendance of relatives, especially from the male family. The mourners who came wearing mourning gowns were in accordance with the close relationship with the deceased. There are four stages in the Chinese ethnic funeral ritual, namely: (1) Before entering the coffin, (2) The coffin entry ceremony and the closure of the casket, (3) the funeral ceremony, and (4) the ceremony after the funeral.

According to Chinese belief, before the body is put in the coffin and the coffin is closed, the offerings must be laid and the burning of incense and small red candles in front of the house in the afternoon. By giving food to spirits, it is believed that sickness and all bad things will pass away.

During the ceremony of placing the body in the coffin, the whole family must wear certain clothes. Boys must wear clothes made of calico that are turned over and given burlap sacks or in this day and age they can be replaced by wearing all white clothes. The head is tied with a piece of calico cloth which is given a piece of burlap or it can be just the arm tied with a piece of white cloth. The clothes worn by daughters and grandchildren wear clothes from calico or can be replaced with white clothes. While the body or coffin has not been buried, a family member must continue to burn the silver foil, under the coffin.

As long as the corpse has not been buried, there are family members who keep the candle flame and the coffin alternating day and night, pay respect and gratitude by bowing their head and body to each guest who visits the place of the deceased's contemporaries to express their condolences and to pray for the deceased. Usually visitors who come to the place of the deceased donate money. The donation money given is usually recorded in a book by someone in charge or the guest records the amount of money donated himself.

Before the funeral ritual is held, customary customs apply according to the closeness and status of family members in paying respect to the deceased. According to ethnic Chinese customs, the oldest members of the family do not need to show respect for the younger ones who have passed away. So, if the deceased is still a child or a baby dies, then no funeral ceremony will be carried out, but will be buried immediately without a funeral ritual.

Close relatives wear white clothes, while relatives who are further away may wear clothes in any colour other than red. Prior to the funeral, an announcement is generally given at the funeral home and also sent to relatives and friends the date and time the funeral ritual takes place. According to custom, the funeral date is generally chosen the best day according to the Chinese lucky calendar.

The procession to the funeral place for the body is carried out by accompanying the car carrying the body on foot or by vehicle to the burial place or cremation place. Deliverers walk to the burial or cremation site only if the burial site is relatively close to the place where the body departed.

Every year, in March (called Ching Bing Day), is the anniversary of the death of a loved one, where relatives come to the burial place of their beloved family to clean the tombstones, mounds of earth around the graves and pray for the deceased as well as being served food. burnt incense, candle flame and spread flowers.

\section{The Symbol's Meaning in the Chinese Ethnic Burial Ritual}

Chinese ethnic funeral rituals have complete rules, principles and conditions that are carried out in funeral activities (Zunzhi, 2014). Closest family relatives or those who have close relations with the deceased (biological children and / or male and female siblings) will wear white shirts, pants and headbands (sometimes they also wear clothes made of burlap material with gray color) is meant to accompany the deceased until the last moment before entering the hereafter and bearing the sins of the deceased. This is a form of devotion and loyalty to the deceased or to loved ones who have been called the Almighty from families who are still living in the world.

Another common practice as a sign of death in a funeral home in Chinese rituals is to put up a white banner over the door of the house to indicate that death has occurred. All relatives will usually gather at 
the home of the family whose family member has passed away to help prepare and carry out all the necessary rituals before the funeral ritual of the deceased. The meaning contained in it is not only as an expression of condolences or to show respect for the deceased, but also to strengthen brotherhood. Traditionally, wearing red clothes during mourning is not allowed, because red is a symbol of joy, so the red clothes worn by visitors and relatives are considered a form of disrespect for families whose family member has died. Traditionally, white clothing is a symbol of condolences. The deceased is worn with new clothes (clean clothes), and other necessities of life such as money, gold, and other valuables, before the body is placed in the coffin as a sign of readiness (provision) to depart from the world to travel to the afterlife. At funeral rituals, flower sprinkles, food offerings and incense are usually served. The offering of food is an indicator of the ongoing interdependence between the deceased and the descendants of the surviving families in the world.

Chinese funeral customs are motivated by the belief that human relations with God or other forces that govern life, such as reincarnation, karmic laws for human actions. The spirits of the ancestors can be asked to come to be entertained (Ceng Beng), respect for the ancestors and clever people (Taopekong), believe in the curse of the ancestors, and actions during life will be repaid in the afterlife are part of the belief in Chinese cultural customs.

Chinese graves are placed on a higher location and the direction of the body's head facing the lowlands or the sea is to increase good fortune (Fengshui). However, based on previous report, in Chinese ethnic culture, a grave is not just a resting place for the deceased, but as a strong symbol that has a sacred meaning in respecting ancestors. So it is not surprising that Chinese ethnic graves are built as comfortable as possible by choosing the right location and direction. Ancestral graves if negligent being cared for then has bad consequences for the fate of the children and grandchildren (Giordimaina et al., 2009).

\section{E. CONCLUSION AND SUGGESTION}

Ethnic Chinese perform funeral rituals as a legacy of ancestral customs and carry out funeral rituals with the belief that there is a relationship between humans and God who governs life.

Procedures, rules, and attitudes are a major part of ethnic Chinese funeral rituals, and also respect for the parents of the deceased is a strict tradition that is adhered to by children and closest relatives, which can be seen during the funeral rituals and after the funeral. The closeness of the Chinese ethnic family is very visible at kinship events, as can also be seen during the funeral rituals of the deceased's relatives.

The funeral ritual to the burial place or the cremation of the body is carried out with pedestrians behind the vehicle carrying the body, if the place of burial or cremation is not far from the funeral home. During the funeral, flowers, offerings, food and burnt incense are served. The ethnic Chinese believe that the location and position of the graves are related to good fortune for the offspring. The best direction is to lean on the plateau and face the lower scenery. Graves are symbols that have a sacred meaning in respecting ancestors so that graves are built majestically and comfortably.

It is important to carry out further research related to Chinese funeral rituals to find out whether local culture affects Chinese ethnic funeral rituals for ethnic Chinese who become citizens in other countries outside China.

\section{ACKNOWLEDGEMENTS}

The author would like to thank the Institute for Research and Community Service of Universitas Bumigora in Mataram, Indonesia, which has provided input on the writing of this article.

\section{REFERENCES}

Bo, P., \& Wei-wei, L. I. (2012). The Transition of the Ghost Superstition in China ' s Funeral Culture. Journal of Anyang Institute of Technology, 5(03), 1-12.

Crowder, L. S. (2000). Chinese Funerals in San Francisco Chinatown: American Chinese Expressions in Mortuary Ritual Performance. The Journal of American Folklore, 113(450), 451.

Farias, P. L., \& Queiroz, J. (2017). Visualizing triadic relations: Diagrams for Charles S. Peirce's classifications of signs. 
36| Jurnal Varian| Vol. 4, No. 1, Oktober 2020, Hal. 31-36

Information Design Journal, 23(2), 127-147.

Giordimaina, A., Vries, K. De, Flood, S., \& Gillis, A. (2009). Death in Chinese Culture final paper, pp. 1-10. Michigan: University of Michigan.

He, Q. (2016). Spectacular Death: Sheng Xuanhuai's Funeral Procession in 1917. Journal of Historical Society for Twentieth-Century China, 41(2), 136-158.

Lin, G. (2013). From " Dying without a Burial Place " to " Resting in Peace ": Research on the Reform of Chinese Funeral Service System under the Four-dimensional Visual Threshold. Journal of Zhejiang University of Humanities and Social Sciences, 3(1), 1-2.

Pasacreta, L. J. (2005). White Tigers and Azure Dragons : Overseas Chinese Burial Practices in The Canadian and American West.

Sankar, L. V., Hock, D., Neo, J., \& Rycker, A. De. (2016). Chinese Culture and Customs in Peranakan Funerals in Malaysia and Singapore. The Journal of the South East Asia Research Centrefor Communications and Humanities, 8(1), 17-36.

Thornbury, C. (2011). Peirce' s General Theory of Signs. Journal of Institute of Education of London, 31(3), 49-57.

Toulson, R. E. (2013). The meanings of red envelopes : Promises and lies at a Singaporean Chinese funeral Rent with DeepDyve. Journal of Material Culture, 18(2), 155-169.

Widmeyer, G. R., \& Arbor, A. (2003). The Trichotomy of Processes: a Philosophical Basis for Information Systems. Australian Journal of Information Systems, 11(1), 3-11.

Wu, X. (2015). The Rites of Mourning in Archaic and Classical Greece and in Pre-Qin China. Fudan Journal of the Humanities and Social Sciences, 8(6), 235-270.

Yakin, H. S. M., \& Totu, A. (2014). The Semiotic Perspectives of Peirce and Saussure: A Brief Comparative Study. Procedia - Social and Behavioral Sciences, 155(1/2), 4-8.

Yick, A. G., \& Gupta, R. (2012). Chinese Cultural Dimensions of Death, Dying, and Bereavement: Focus Group Findings. Journal of Cultural Diversity, 9(2), 34-42.

Zunzhi, L. (2014). A Brief Analysis of Funeral Rituals and Related Material Culture in Han Dynasty. Nankai Journal, 3(01), 21-22. 